\title{
ERRATUM
}

\section{Screening duplex ultrasonography in neurosurgery patients does not correlate with a reduction in pulmonary embolism rate or decreased mortality}

TO THE READERSHIP: An error appeared in the article by Dickerson et al. (Dickerson JC, Harriel KL, Dambrino RJ IV, et al: Screening duplex ultrasonography in neurosurgery patients does not correlate with a reduction in pulmonary embolism rate or decreased mortality. $J$ Neurosurg [epub ahead of print April 26, 2019; DOI: 10.3171/2018.12.JNS182800]).

A clarification is needed in the first sentence of the Results section. The phrase "Of the 2532 reviewed patients" should be "Of the 2532 reviewed admissions." The corrected sentence appears below.

Of the 2532 reviewed admissions, 485 met criteria for the routine-LEDUS group and 504 for the selective-LEDUS group.

The article has been corrected online as of October 25, 2019.

Chad W. Washington, MS, MD, MPHS

University of Mississippi Medical Center, Jackson, MS

CORRESPONDING ARTICLE See pp 1589-1597.

INCLUDE WHEN CITING

Published online October 25, 2019; DOI: 10.3171/2019.9.JNS182800a.

CAANS 2020, except where prohibited by US copyright law 